\title{
Mothers and fathers attending the International Child Development Programme (ICDP) in Norway
}

\author{
19 March 2014
}

\section{Acknowledgements}

The evaluation has been funded by the Norwegian Ministry for Children, Equality, and Social Inclusion. The authors want to thank the Ministry and the Norwegian Directorate for Children, Youth and Family Affairs for their support and positive collaboration, and the ICDP facilitators and trainers, as well as the caregivers who gave of their time to the evaluation. Further thanks go to Trine Gerlyng, Ylva Snekkvik, Marit Reer, Hilde Breck, and Kristina Aas Fure for their assistance in data collection and registration. 


\begin{abstract}
Fathers are understudied in parent training studies. This study investigates whether mothers and fathers benefit equally from participating in the International Child Development Programme (ICDP) implemented as a community-wide programme in Norway in their parenting behaviour, perceived child difficulties and their psychosocial health. The questionnaire study used a pre-post design comparing 105 mothers and 36 fathers who attended a regular ICDP course. Results showed that the mothers and fathers differed on parenting behaviours prior to the course but showed similar changes, including on emotional and regulative aspects of parenting and autonomy supportive behaviours. However, only the mothers perceived a decrease in their child's difficulties after the course while the fathers showed a greater increase in behaviours assumed to support the child's meaning-making and in self-efficacy, and a greater decrease in anxiety after the course. ICDP courses appear to be a useful tool for supporting both mothers and fathers in their parenting role.
\end{abstract}

Keywords: Fathers, mothers, parenting, psychosocial well-being, ICDP 
Even though fathers have traditionally spent less time parenting their children compared to mothers, they now undertake an increasing range of childcare tasks (Gregory \& Milner, 2008; Hook \& Wolfe, 2011) with changing employment patterns and social attitudes (Gerson, 2002; Milkie, Mattingly, Nomaguchi, Bianchi, \& Robinson, 2004). In Norway, there has been a notable change in the responsibilities of mothers and fathers of preschool children, with a threefold increase in fathers' time commitment on household chores and caregiving between 1980 and 2010. Correspondingly, women spent less time on chores and more on employment (Kitterød, 2012). The equalization of caring responsibilities is supported by Norwegian family policy (Lappegard, 2008), and generous paternity leave of 12 weeks which 64.6 per cent of Norwegian fathers took in 2010 (Bringedal \& Lappegård, 2012; Statistics Norway, 2013).

Fathers' involvement in parenting may contribute to better social competence, cognition and language, psychological adjustment, emotional regulation and peer relationships, and fewer conduct problems in children (e.g. Amato \& Rivera, 1999; Parke et al., 2002; Cabrera, Shannon \& Tamis-LeMonda, 2007). A review of more than 100 studies found that loving and nurturing parenting from both mothers and fathers was important for child happiness, well-being, and social and academic success (Rohner \& Venziano, 2001). These positive effects may be partly due to the presence of two committed parents rather than the gender of the parent (Biblarz \& Stacey, 2010).

Research has documented differences in parenting styles between mothers and fathers. Mothers are more involved with their children than fathers, regardless of child age (Pleck \& Masciadrelli, 2004), and parenting studies have found that mothers generally score higher on parenting measures than fathers, display more affection and warmth and engage in more rule setting and supervision (Biblarz \& Stacey, 2010). These qualities may be present in fathers but less likely to be expressed when mothers are around (Biblarz \& Stacey, 2010). Gender 
differences in parenting may vary according to the child's gender (Cabrera, Tamis-LeMonda, Bradley, Hofferth \& Lamb, 2000; Lamb, 2000; Nettle, 2008), although not consistently (Marsiglio, 1991). This has been shown with discipline (Starrels, 1994) and prediction of externalising and internalising behaviours (Browne, Odueyungbo, Thabane, Byrne, \& Smart, 2010).

Despite the need to study and promote positive parenting in fathers and mothers, fathers tend to be under represented in parent training studies (Fabiano et al., 2012). A review of behavioural training for parents with children with attention-deficit/hyperactivity disorder (ADHD) found that only 13 per cent of the studies included father information (Fabiano, 2007). Similarly, a review of group-based parent training programmes found only four of 48 studies reporting on fathers' changes in psychosocial functioning (Barlow, Smailagic, Huband, Roloff, \& Bennett, 2012) and none reported on depressive symptoms, confidence or partner satisfaction in the fathers. Fathers are thus less likely to be studied and even when included their results fade into the female majority.

Most research on the effect of parenting programmes on fathers is conducted with parents or children with special challenges such as ADHD or conduct difficulties rather than broader populations (Long, 2007). These studies have shown beneficial effects of behavioural parent training for fathers on increasing praise and reducing negative father verbalizations, over reactive and lax discipline behaviours and child problem behaviour intensity, hyperactivity and aggression (Fabiano et al., 2012; Danforth, Harvey, Ulaszek and McKee, 2006), although meta-analyses of such parenting programmes have found a larger effect on mothers than on fathers (Fletcher, Freeman \& Matthey, 2011; Lundahl, Tollefson, Risser, \& Lovejoy, 2008).

The International Child Development Programme (ICDP) is a psychosocial parenting programme developed by Professor Karsten Hundeide and Henning Rye (University of Oslo) 
with international colleagues in the 1980s. Hundeide formulated the ICDP manual in the early 1990s with an updated version published in 2010 (Hundeide, 2010). The programme content is based on developmental and humanistic psychology and extensive field experience (Hundeide \& Rye, 2010). The ICDP is formulated as three emotional, comprehension and regulative "dialogues" for good caregiver-child interaction and eight guidelines illustrating these dialogues (Hundeide, 2001). The programme aims to improve parenting practices and thereby child development and well-being by supporting sensitive adult adjustment and empathy. The approach is facilitative and thought to be culturally sensitive by identifying and reactivating local practises rather than imposing practices from the outside. It is used in more than 30 countries in collaboration with organizations such as Save the Children, Unicef, Care, and World Health Organization.

The ICDP focuses on strengthening emotional interaction and regulation, areas where fathers have been shown to score lower than mothers (Biblarz \& Stacey, 2010) using a noninstructive approach, which might contribute to increasing the effectiveness of the programme on fathers compared to other programmes. In Norway, ICDP courses are implemented nationwide and provided as a preventive measure to mothers and fathers in the general population by the Ministry of Children, Equality, and Social Inclusion (Program for foreldrerettleiing, 2014).

One recent study reported improved parental attitudes and child rearing skills after ICDP in a community-wide sample of caregivers in Norway (Sherr, Skar, Clucas, von Tetzchner \& Hundeide, 2013). Another study reported more positive child regulation, fewer child conduct problems and better adjustment in children in a community-wide sample of caregivers who had attended ICDP meetings compared to a socio-geographical matched comparison group in Mozambique (Skar, Sherr, Clucas, \& von Tetzchner, 2014). Several non-published and generally smaller-scale and/or less rigorous (often internal) evaluations of 
MOTHERS AND FATHERS ATTENDING ICDP 6

the ICDP have also been carried out in other countries such as Sweden, Denmark, Angola and Colombia, offering some additional support for the effectiveness of ICDP in different cultures (ICDP, 2014). However, no study has investigated the effects of the programme for fathers separately. The present study investigates whether mothers and fathers show similar changes in parenting behaviour and self-reported mental health after attending a generally implemented ICDP course in Norway and the possible differences related to sons and daughters.

\section{Methods}

\section{Participant recruitment and design}

The study used a pre-post between-subject group design with mothers $(\mathrm{N}=105)$ and fathers $(\mathrm{N}=36)$ completing questionnaires before and after the ICDP course. A total of 69 regular ICDP groups were approached during the data collection period (October 2008-March 2010). The ICDP groups were run at kindergartens and child health centres and recruited through open billboard information, staff advertisement or invitation. At the first meeting, the parents were informed about the evaluation project and signed consent was obtained from 269 parents; 64 fathers (64.6\% of participating fathers present at the first meeting) and 202 mothers (58\% of participating mothers present at the first meeting), whereas three did not indicate their gender. Thirty-six fathers and 105 mothers returned a second questionnaire after the course (52.4\%) with one reminder.

\section{Procedure}

The study was approved by the Regional Committee for Medical and Health Research Ethics and the Norwegian Social Science Data Services. The parents completed the first questionnaire during their first meeting and the second questionnaire during the last group meeting or returned it by mail.

\section{ICDP}


Mothers and fathers with children of all ages can participate in ICDP courses. ICDP courses are implemented in a group format including group discussions, caregiver assignments and report back. Trained facilitators with standardized ICDP training (Hundeide, 2001) guide and support the process (see www.icdp.info for details). A filter-down approach is used where qualified trainers train new facilitators, often staff working in kindergartens and child health centres (Hundeide, 2001). Groups usually consist of 5-10 caregivers attending eight two-hour meetings, each dedicated to a guideline for interaction illustrating one of the three interaction dialogues.

\section{Materials}

The questionnaire consisted of demographic questions about gender, civil status, age, place of birth, education and employment of the parents, number of people in the home, number of children and age and gender of the focus child (the child closest in age to four), standardized scales as well as non-standardized items about the caregiver's relationship with the focus child and the family:

Activities with the child. The Parent-Child Activity Scale (Bigner, 1977) consists of 25 items scored on a Likert scale from 1 (never) to 5 (always). The summed score could range from 25 to $125(\alpha=.87)$.

Discipline. Seven items on positive discipline were created (e.g. "praised my child for making a good choice", "explained a better alternative behaviour") based on Conflict Tactics Scales (Straus, Hamby, Finkelhor, Moore, \& Runyan, 1998), with the caregiver indicating how frequently s/he engaged in the behaviours $(0,1-2,3-10$ or more than 10 times $)$. The positive discipline items all loaded on one factor in a principle components analysis (PCA) $(\alpha$ $=.77$ ), and were therefore accepted as representing a scale with a summed score ranging from 0 to 105 was created by adding midpoints for the response categories. 
MOTHERS AND FATHERS ATTENDING ICDP 8

Hours spent with the child. Participants indicated how many hours the mother and the father spent with the child on weekdays.

Commotion in the household. The Household Chaos Scale (Matheny, Wachs, Ludwig, \& Phillips, 1995) consists of 15 items scored true or false. The summed score can range from 0 to $15(\alpha=.75)$. A higher score represents a more chaotic, disorganized and hurried household.

Parenting strategy. Five items were created to measure caregivers' parenting strategy with a focus on the comprehension dialogue component of the ICDP programme (e.g. “expanding the child' experiences by giving explanations and telling stories") and scored 1 (strongly disagree) to 6 (strongly agree). A parenting strategy scale was created based on these items as they loaded moderately to strongly (loadings $\geq 0.5$ ) on one factor in a PCA and had good inter-item consistency $(\alpha=.70)$. The summed score could range from 5 to 30 . Negatively phrased items were reverse coded, such that a higher score was always better.

Engagement with the child. Ten bipolar items were created to measure key parenting aspects linked to the ICDP dialogues for interaction and particularly the emotional dialogue, scored in counterbalanced order from 1 to 7 . An "engagement scale" was created with eight of the items (items good-bad, sensitive-insensitive, loving-unloving, kind-aggressive, adjusting-directing, talkative-non-talkative, rewarding-punitive, engaged-unengaged), which loaded on one factor in a PCA $(\alpha=.85)$. A lower score on the scale represented greater emotional and interactive engagement.

Child management. Twenty-two items scored on a Likert scale from 1 (agree completely) to 5 (completely disagree) were created to measure parents' perceived ability to manage their child with a focus on the emotional, comprehension and regulative dialogue in the ICDP and support of the child' independence and autonomy (e.g. "I do not show much love to my child" (reverse coded), "I set limits for my child when s/he behaves badly", "I 
trust my ability to take good care of my child"). The 22 items all loaded on one factor in a PCA $(\alpha=.88)$. The items were therefore accepted as representing a scale and a mean score was created, which could range from 1 to 5. A lower score represented more positive child management behaviours and greater perceived ability to manage their child.

Happiness with partner. A visual analogue scale scored from 0 (extremely unhappy) to 6 (perfectly happy) taken from the Dyadic Adjustment Scale (Spanier, 1976).

Child strengths and Difficulties. The Strength and Difficulties Questionnaire (SDQ, Goodman, 1999) is a brief behavioural screening questionnaire about the child with five subscales (Emotional Symptoms, Conduct Problems, Hyperactivity, Peer Problems, Prosocial) and an impact supplement assessing whether the respondent thinks the child has a problem, and if so, assesses chronicity, distress, social impairment, and burden to others. Three scores were generated: total difficulties score ranging from 0 to 40 (the sum of items from the first four subscales, $\alpha=.73$ ), a prosocial score ranging from 0 to 10 (the sum of items from the prosocial subscale, $\alpha=.72$ ) and an impact score ranging from 0 to 10 (derived from questions on overall distress and social impairment from the impact supplement).

Health and quality of life. Two SF-36 VAS scales were used (Ware, Snow , Kosinski, \& Gandek, 1993), scored 0 on the extreme left and 100 on the extreme right.

Loneliness. The UCLA Loneliness Scale (Russell, 1996) consists of seven items scored from 1 (hardly ever/ever) to 3 (often). The summed score can range from 7 to $21(\alpha=.76)$.

Life satisfaction. The Satisfaction with Life Scale (Diener, Emmons, Larsen, \& Griffin, 1985) with 5 statements scored from 1 (disagree completely) to 7 (strongly agree). The summed score can range from 5 to $35(\alpha=.87)$.

Self-esteem. The 10 item Rosenberg (1965) Self-esteem Scale allowed for a summed score with a range from 0 to $30(\alpha=.83)$. 
Self-efficacy. The Generalized Self-Efficacy Scale (Schwarzer \& Jerusalem, 1995) consists of 10 items scored from 1 (not at all true) to 4 (exactly true). The summed score can range from 10 to $40(\alpha=.87)$.

Trait emotions. The Basic Emotion Trait Test (BETT, Vittersø, Dyrdal, \& Røysamb, 2005) contains 15 items, covering five basic emotions (Pleasure, Explore, Anger, Fear and Sadness). Each item is scored from 1 (never) to 7 (all the time). Only the Anger subscale had acceptable inter-item reliability $(\alpha=.75)$ in our sample and is reported.

Anxiety and depression. The Hospital Anxiety and Depression Scale (HADS) (Zigmond \& Snaith, 1983) consists of seven anxiety and seven depression items, scored from 0 (not at all) to 3 (very often, most of the time, definitely, very much). Summed scores for anxiety $(\alpha=.81)$ and depression $(\alpha=.66)$ were created, each from 0 to 21 .

\section{Statistical analyses}

Chi-squared tests and t-tests were used to compare mothers and fathers on demographic variables before the course and to compare the parents who completed both questionnaires with parents who completed only the first one.

T-tests were used to compare the scores of mothers and fathers before and after the course, as well as scores from before to after the course in each group. A 2 (parent gender: mother/father) X 2 (time: before/after) mixed ANOVA with repeated-measures on time of measurement was used to investigate interaction effects of time and group that may indicate different change patterns in fathers and mothers.

Additional analyses using multiple linear regression or two-level random intercept regression models with repeated measures nested within parents were used to adjust for confounding variables when these were related to the outcome. These analyses were done to explore whether the differences in scores or change scores between the mothers and fathers were due to the gender of the parent or to other differences between the groups (parent age, 
child age, number of people in the home). Multilevel regression models can usefully analyse repeated measures data and adjust for continuous predictors without relying on some of the more restrictive ANCOVA assumptions (Kwok et al., 2008). Additional exploratory analyses were also conducted to examine whether differential effects of the intervention on parent and child outcomes for mothers and fathers varied according to the gender of the child. For these analyses, child gender (girl/boy) was entered in the 2 (parent gender: mother/father) X 2 (time: before/after) mixed ANOVA to uncover any three-way interactions between parent gender, child gender and time.

\section{Results}

\section{Description of participants}

Only participants who completed both questionnaires are included in the analyses. Among the 36 fathers, 69.4 per cent had a higher education, 91.7 per cent were born in Norway, 80.6 per cent were married or with a partner, 86.1 per cent were in full-time employment and 41.7 per cent of the focus children were female with 44.4 per cent being male (Table 1). The fathers were 38.41 years old $(S D=6.15$, range $=27-60)$, had an average of 1.86 children $(S D$ $=.73$, range $=1-3)$ and were 3.14 people in the home $(S D=1.26$, range $=1-5)$. The focus child had an average age of 5.13 years $(S D=3.93$, range $=.5-16)$. Among the 105 mothers, 55.2 per cent had a higher education, 90.5 per cent were born in Norway, 92.4 per cent were married or with a partner, 44.8 per cent were in full-time employment and 48.6 per cent of the focus children were female with 41 per cent being male (Table 1). The mothers were 33.41 years old $(S D=5.71$, range $=23-51)$, had an average of 1.93 children $(S D=.73$, range $=1-3)$ and were 3.66 people in the home $(S D=1.06$, range $=1-5)$. The focus child had an average age of 3.60 years $(S D=1.91$, range $=.5-10)$.

Table 1 
Table 1 shows that the fathers were significantly more likely than the mothers to be employed full time (86.1 vs. $44.8 \%)$. Fathers were also significantly older $(t[1,138]=4.35$, $p<.001)$, reported on an older focus child $(t[1,127]=2.12, p=.041)$, and had fewer people in the home $(t[1,136]=-2.08, p=.039)$. The groups did not differ on place of birth, education, civil status, number of children and gender of focus child.

There were few differences between participants who completed only the first and those who completed both questionnaires. Mothers who completed both questionnaires were more likely to be married or with a partner $(92.4 \%$ of 105 vs. $77.9 \%$ of 95$), X^{2}[1,200]=$ $8.44, p=.004)$ with lower depression $(M=2.96$ vs. $3.90 ; t[1,192]=-2.47, p=.015)$. There were no other significant differences. There were no demographic differences between the fathers who completed only the first and the fathers who completed both questionnaires. The fathers who completed both questionnaires gave a higher child SDQ impact score $(M=.85$ vs. . $25 ; t[1,62]=2.08, p=.042)$ and scored higher on engagement $(M=2.87$ vs. $2.35 ; t[1$, $50]=2.19, p=.033)$ and child management $(M=2.11$ vs. $1.83 ; t[1,37]=2.04, p=.049)$, indicating a lower function for the fathers who completed both questionnaires, with no significant differences on other variables.

\section{Attendance}

The courses consisted of eight meetings; among the fathers, $10(27.8 \%)$ attended all the meetings and $10(27.8 \%)$ missed one meeting, $10(27.8 \%)$ two meetings and $3(8.3 \%)$ more than two meetings ( 3 missing). Among the mothers, 38 (36.2\%) attended all the meetings and $27(25.7 \%)$ missed one meeting, $12(11.4 \%)$ two meetings and $10(9.5 \%)$ more than two meetings (18 missing). There was no significant difference in attendance between fathers and mothers or relationship between number of meetings attended and change in outcome scores in mothers or fathers.

\section{Differences between mothers and fathers before the course}


Table 2 shows the fathers' and mothers' scores on parenting, child and psychosocial measures with significant group differences before and/or after the course and corresponding test results. Before attending the course, the fathers scored significantly lower than the mothers on parenting strategies $(M=20.97$ vs. 23.20). The fathers' and mothers' scores on engagement ( $M=2.87$ vs. 2.30$)$ and child management $(M=2.11$ vs. 1.83$)$ differed significantly (note that on engagements and child management, a higher score indicates lower function). The differences in activities with the child ( $M=94.11$ vs. 105.08) and positive discipline ( $M=35.95$ vs. 45.09$)$ were significant, but the difference for positive discipline was not significant when adjusting for the effect of child age. The hours fathers spent with the child on weekdays was significantly higher according to the fathers compared to the mothers $(M=3.07$ vs. 2.00$)$, although this difference disappeared when adjusted for age. Table 2

Fathers scored significantly lower than the mothers on life satisfaction $(M=23.68$ vs. 26.04) and life quality $(M, S D=74.43$ vs. 80$)$ but these effects were not significant when adjusted for parent age.

\section{Changes in mothers and fathers from before to after the course}

Table 3 shows fathers' and mothers' scores on parenting, child and psychosocial measures before and after the ICDP course and corresponding test results. Table 3 shows that on parenting measures, both fathers and mothers changed significantly from before to after the course on parenting strategies $(M=20.97$ and 22.53 vs. 23.26 and 23.86). There was a significant interaction of parent gender and time for parenting strategy reflecting a greater increase in parenting strategy scores in fathers compared to mothers after the course $(F=$ $\left.5.79, p=.018, \eta \rho^{2}=.05\right)$. There were also significant changes in fathers' and mothers' scores on engagement $(M=2.95$ and 2.53 vs. 2.31 and 2.12), positive discipline $(M=32.26$ and 
39.54 vs. 46.38 and 53.89$)$ and child management $(M=2.13$ and 1.92 vs. 1.83 and 1.74$)$, indicating improved engagement, positive discipline and child management. Table 3

Table 3 shows that the mothers perceived significantly less child difficulties after the course $(M=8.84$ and 6.97$)$, while the fathers' score increased slightly and non-significantly $(M=9.70$ and 10.23). This was reflected in a significant interaction effect of gender and time on SDQ total difficulties $\left(F=9.28, p=.003, \eta \rho^{2}=.07\right)$.

For parental psycho-social problems (see Table 3), both fathers and mothers reported significantly lower levels of anxiety $(M=5.84$ and 4.39 vs. 5.50 and 5.02), with a larger decrease in anxiety in fathers than in mothers after the course $\left(F=4.39 ; p=.038, \eta \rho^{2}=.03\right)$. The mothers had significantly lower scores for household commotion after the course $(M=$ 2.61 and 2.19) while the reduction in the fathers' scores was not significant. The fathers had significantly higher scores on self-efficacy after the course $(M=29.03$ and 31.03$)$ while the mothers' scores remained stable, and the interaction effect of parent gender and time was significant $\left(F=6.10 ; p=.015, \eta \rho^{2}=.05\right)$. The fathers also had lower scores for health after the course $(M=81.76$ and 77.50). An interaction effect approaching significance $(F=3.86, p$ $=.052, \eta \rho^{2}=.03$ ), showed that health scores decreased for the fathers and increased slightly for the mothers.

None of the other differences between changes in the fathers' and mothers' scores from before to after the course resulted in significant interaction effects, indicating similar patterns of change. All significant time and interaction effects remained significant after adjusting for confounding variables.

There was one significant three-way interaction between parent gender, child gender and time, indicating that the gender of the focus child had little influence on how the mothers and fathers reacted to the course. The three-way interaction for SDQ total difficulties $(F=$ 
$\left.4.40, p=.038, \eta \rho^{2}=.04\right)$ indicated when followed-up a non-significant increase in fathers' scores for sons $(M, S D=8.67,1.97$ and $10.25,5.12)$ and a slight non-significant decrease in their scores for daughters $(M, S D=10.07,6.72$ and 9.67, 5.45), and a significant decrease in the mothers' scores for sons $(M, S D=9.83,4.49$ and $6.91,3.99, t=3.19, p=.003)$ as well as for daughters $(M=8.45,4.93$ and $7.16,4.42, t=3.70, p=.001)$.

\section{Differences between mothers and fathers after the ICDP course}

Table 2 shows that there were some changes after the course, with a tendency for mothers and fathers to score more similarly after the course. The fathers still scored significantly lower than the mothers on parenting strategies $(M=22.08$ vs. 23.89$)$, positive discipline $(M=$ 37.79 vs. 53.35$)$ and activities $(M=91.42$ vs. 102.9$)$ and higher on engagement $(M=2.54$ vs. 2.10), even after adjusting for confounding variables. However, the group difference was no longer significant for child management, possibly reflecting a somewhat larger change in the fathers' than in the mothers' scores. Fathers reported more hours spent with the child on weekdays than the mothers reported for the fathers ( $M=4.35$ vs. 2.19), even after adjusting for confounding variables.

After the course, there was a significant difference in the fathers' and mothers' perception of the child's SDQ score ( $M=10.09$ vs. 6.89$)$, likely linked to mothers' score decreasing while the fathers' score increased. As before the course, there was a significant group difference in life satisfaction $(M=24.32$ vs. 26.41$)$ but the difference was not significant when adjusted for parent age. While the difference in loneliness and depression only approached significance before the course, fathers had significantly higher loneliness scores $(M=13.40$ vs. 11.76$)$ and depression scores $(M=4.14$ vs. 2.83$)$ after the course. The change for depression possibly reflected the small increase in scores of the fathers and the small decrease in scores for the mothers. The fathers scored significantly higher than the 
MOTHERS AND FATHERS ATTENDING ICDP 16

mothers on self-efficacy after the course $(M=31.15$ vs. 28.72$)$ but this difference was not significant when adjusted for child age.

\section{Discussion}

The overall results suggest that both mothers and fathers showed a similar pattern of change after attending the ICDP. There were significant changes in scores for parenting strategies, positive discipline, engagement and child management. These changes are in line with the emotional and regulative dialogues underpinning of the programme (Hundeide, 2001). The findings indicate a potential for positive change in both fathers and mothers when neither parents nor child belong to an identified at-risk group. In Norway, there has been an increase in the number of children and families referred to the child protection system, partly due to a lack of necessary parenting skills (Clausen \& Valset, 2012). Attending ICDP courses may have a preventive effect.

The mothers scored better on most of the measures, which might be reflecting more experience with parenting. They scored higher on parenting strategies, emotional and interactive engagement, and child management and participated in more activities with the child. These differences are consistent with other studies which also found that mothers generally scored higher on parenting measures than fathers (Biblarz \& Stacey, 2010), particularly on warmth and involvement (Russel et al., 1998; Starrells, 1994), and the use of reasoning supporting the child's meaning-making (Russel et al., 1998). Therefore, it is especially promising that different patterns of change favouring the fathers were observed for parenting strategies, parental self-efficacy and anxiety. These differences remained after adjusting for parent and child age and number of people in the home. It was not possible to adjust for employment given that only four fathers were not in full time employment.

The fathers improved more than mothers on the parenting strategy scale reflecting the comprehension dialogue with the child. It is likely that the fathers had less experience with 
caring and parenting and hence a greater potential for developing parenting skills, as the mothers scored high on child management both before and after the course. Studies suggest that maternal self-efficacy and parenting competence are positively associated in parents who have good knowledge about development (Hess, Teti \& Hussey-Gardner, 2004). It is likely that the ICDP course increased the fathers' knowledge about child development, contributing to making them more competent parents, increasing parental self-efficacy and reducing anxiety. The fathers tended to feel more lonely than the mothers, in line with Norwegian data (Normann, 2010), and it might be that support from others in the group made the fathers more confident about parenting, with positive effects on self-efficacy and anxiety. A review of parental self-efficacy supports a relationship between parental self-efficacy and parental confidence, and concludes that parental self-efficacy is a "possible predictor of parental competence and child functioning, or perhaps an indicator of risk", and may be "an appropriate target for prevention and intervention efforts" (Jones \& Prinz, 2005, p. 341). The ICDP approach seems to an effective tool for this purpose.

The fathers reported that they spent more time with the child after participating in the ICDP and - complementary - there was a trend for them reporting that the mother spent less time with the child. This might be due to fathers being more aware of the time they spent with their children, and may not reflect an actual change in behaviour, although this may be a consequence in a longer perspective. An increase in the number of hours fathers spend with their children is an explicit goal of Norwegian policies (Kitterød \& Lyngstad, 2006). Fathers could have become more involved since they also improved their parenting strategies, which could have a positive impact on their children's regulation of their emotions and impulses (Allen \& Daly, 2007), self-esteem and depression (Dubowitz et al., 2001), calling for longerterm studies of the effects of parental guidance for fathers on children and families. 
An unexpected finding was that only the mothers attributed fewer difficulties to the child after than before the course. There was a trend for fathers attributing more difficulties to their sons (but not their daughters) after compared to before the course. It is possible that the fathers with sons as a result of spending more time with the child became more aware of behaviour problems, which usually are more prominent in boys (Dodge, Coie \& Lynam, 2006). The fathers with daughters may have found it easier to "redefine" the daughter's behaviour in line with the ICDP principles (see MacKenzie \& McDonough, 2009).

The present study has some limitations. First, because there was no control group, one cannot conclude that changes observed after the course were due to the course itself rather than time or unrelated environmental events. However, there is evidence that parents who attended an ICDP course showed significantly greater positive change on several parenting and psychosocial measures than a matched comparison group of parents who did not attend such a course (Sherr et al., 2013). Second, the parents were a self-selected group and it might be that those who are most motivated to receive guidance on parenting signed up for the course. Furthermore, the sample size for fathers was small, so findings might not generalise to all caregivers attending ICDP groups. However, the modest number of father participants is linked to a limited father programme participation, a difficulty that has been pointed to in several other studies (e.g. Fletcher et al., 2011; Sanders, Dittman, Keown, Farruggia, \& Rose, 2010). Third, multiple statistical tests may have increased the probability of Type 1 errors. Yet, it was not appropriate to adjust for multiple comparisons given the large number of tests and correlations between outcomes (Bender, 2001) and the small sample size also likely resulted in less power to detect statistically significant differences. The analyses should be seen as exploratory rather than leading to definitive conclusions (Bender, 2001). Fourth, the data is based on self-report and further research needs to assess whether changes are also taking place in parents' behaviours after attending an ICDP course. Fathers in Norway with 
high education spend more time with their children than fathers with lower educational levels (Kitterød \& Lyngstad, 2006), and long-term studies should investigate whether general parenting programmes, like the ICDP, would increase the amount of time fathers with high and low educational levels spend with their children.

Despite the limitations, the study suggests that both mothers and fathers can derive benefits from attending an ICDP or similar parenting courses. This programme seems promising as fathers actually appeared to benefit even more than mothers in some respects, and it might be that the facilitative rather than instructive methodology in the ICDP programme contributes to this (see for example Cabrera et al., 2000). Greater efforts need to be deployed to attract a larger number of fathers to participate in parenting programmes. An even greater focus on issues of direct relevance to fathers, or separate programmes for mothers and fathers might lead to an increase in father participation rates (Fabiano, 2007). 


\section{References}

Allen, S. \& Daly, K. (2007). The effects of father involvement: An updated research summary of the evidence. Centre for Families, Work and Well-Being, University of Guelph. Accessed 26/10/2013 from http://www.fira.ca/cms/documents/29/Effects_of_Father_Involvement.pdf

Amato, P. R., \& Rivera, F. (1999). Paternal involvement and children's behaviour problems. Journal of Marriage and Family, 61, 375-384.

Barlow J., Smailagic, N., Huband, N., Roloff, V., \& Bennett, C. (2012). Group-based parent training programmes for improving parental psychosocial health. Cochrane Database of Systematic Reviews, Issue 6. doi: 10.1002/14651858.CD002020.pub3.

Bender, R. (2001). Adjusting for multiple testing - when and how? Journal of Clinical Epidemiology, 54, 343-349.

Biblarz, T. J., \& Stacey, J. (2010). How does the gender of parents matter? Journal of Marriage and Family, 72, 3-22. doi: 10.1111/j.1741-3737.2009.00678.x.

Bigner, J. J. (1977). Attitudes toward fathering and father-child activity. Home Economics Research Journal, 6(2), 98-106. doi: 10.1177/1077727X7700600201

Bringedal, K. H. \& Lappegård, T. (2012). Bruk av foreldrepermisjonen: Likere deling av foreldrepermisjonen. [Usage of the parental payments: more equal sharing of the parental leave]. Samfunnsspeilet, 26(1), 13-18.

Browne, D. T., Odueyungbo, A., Thabane, L., Byrne, C., \& Smart, L. A. (2010). Parentingby-gender interactions in child psychopathology: Attempting to address inconsistencies with a Canadian national database. Child Adolescent and Psychiatry and Mental Health, 4:5. 
Cabrera, N. J., Tamis-LeMonda, C. S., Bradley, R. H., Hofferth, S., \& Lamb M, E. (2000). Fatherhood in the twenty-first century. Child Development, 71, 127-136. doi: $10.1111 / 1467-8624.00126$

Cabrera, N. J., Shannon, J. D. \& Tamis-LeMonda, C. (2007). Fathers' influence on their children's cognitive and emotional development: From toddlers to pre-k. Applied Development Science, 11(4), 208-213.

Clausen, S. E. \& Valset, K. (2012). Spedbarn og småbarn med tiltak fra barnevernet 19952008: Utbredelse av omsorgssvikt og risikofaktorer. [Infants and toddlers with childwelfare services 1995-2008: Prevalence of neglect and risk factors]. Tidsskrift for Norsk Psykologforening, 49(7), 643-648.

Danforth, J. S., Harvey, E., Ulaszek, W. R., \& McKee, T. E. (2006). The outcome of group parent training for families of children with attention-deficit hyperactivity disorder and defiant aggressive behavior. Journal of Behavior Therapy and Experimental Psychiatry, 37, 188-205. doi: 10.1016/j.jbtep.2005.05.009

Diener, E., Emmons, R. A., Larsen, R. J., \& Griffin, S. (1985). The Satisfaction With Life Scale. Journal of Personality Assessment, 49(1), 71-75. doi: 10.1207/s15327752jpa4901_13

Dodge, K. A., Coie, J. D. \& Lynam, D. (2006). Aggression and antisocial behavior in youth. In W. Damon, R. M. Lerner \& N. Eisenberg (Eds.), Handbook of child psychology, Volume 3. Social, emotional, and personality development, Sixth edition (pp. 719-788). New York: John Wiley.

Dubowitz, H., Black, M. M., Cox, C. E., Kerr, M. A., Litrownik, A. J., Radhakrishna, A., ..., \& Runyan, D. K. (2001). Father involvement and children's functioning at age 6 years: A multisite study. Child Maltreatment, 6(4), 300-309. 
Fabiano, G. A. (2007). Father participation in behavioral parent training for ADHD: Review and recommendations for increasing inclusion and engagement. Journal of Family Psychology, 21(4), 683-693. doi: 10.1037/0893-3200.21.4.683

Fabiano, G. A., Pelham, W. E., Cunningham, C. E., Yu, J., Gangloff, B., Buck, M., Linke, S., Gormley, M., \& Gera, S. (2012). A waitlist-controlled trial of behavioral parent training for fathers of children with ADHD. Journal of Clinical Child and Adolescent Psychology, 41(3), 337-345. doi: 10.1080/15374416.2012.654464.

Fletcher, R., Freeman, E., \& Matthey, S. (2011). The impact of behavioural parent training on fathers' parenting: A meta-analysis of the Triple P-Positive Parenting Program. Fathering: A Journal of Theory, Research, and Practice about Men as Fathers, 9(3), 291-312. doi: 10.3149/fth.0903.291

Gerson, K. (2002). Moral dilemmas, moral strategies, and the transformation of gender. Gender and Society, 16(1), 8-28. doi: 10.1177/0891243202016001002

Goodman, R. (1999). The extended version of the strengths and difficulties questionnaire as a guide to child psychiatric caseness and consequent burden. Journal of Child Psychology and Psychiatry, 40, 791-799. doi: 10.1111/1469-7610.00494

Gregory, A., \& Milner, S. E. (2008). Fatherhood regimes and father involvement in France and the UK. Community, Work and Family, 11(1), 61-84. doi: $10.1080 / 13668800701419391$

Hess, C. R., Teti, D. M. \& Hussey-Gardner, B. H. (2004). Self-efficacy and parenting of high-risk infants: The moderating role of parent knowledge of infant development. Journal of Applied Developmental Psychology, 25(4), 423-437.

Hook, J. L. \& Wolfe, C. M. (2011). New fathers? Residential fathers' time with children in four countries. Journal of family issues, 33(4), 415-450. doi: $10.1177 / 0192513 X 11425779$ 
Hundeide, K. (2001). Ledet samspill fra spedbarn til skolealder. Håndbok til ICDPs sensitiviseringsprogram [Guided interaction from infancy to school age. Handbook to ICDP's sensitivity programme]. Oslo: Vett og Viten.

Hundeide, K. (2010). The essence of human care: an introduction to the ICDP programme. Accessed 7/3/2014 from www.icdp.info/karsten-hundeides-manual-

Hundeide, K. \& Rye, H. (2010). The early history, development and basic values of ICDP, accessed 7/3/2014 from http://www.icdp.info/api/media/media/30

International Child Development Programme (2014). ICDP - International Child Development Programme - evaluation documents. Accessed 10/03/2014 from http://www.icdp.info/evaluation.

Jones, T. L. \& Prinz, R. J. (2005). Potential roles of parental self-efficacy in parent and child adjustment: A review. Clinical Psychology Review, 25(3), 341-363.

Kitterød, R. H. \& Lyngstad, J. (2006). Mest samvær blant ressurssterke fedre? Betydningen av inntekt og utdanning for samværsfedres kontakt med barna [Most interaction among resourceful fathers? The importance of income and education for non-resident father's contact with their children]. Statistics Norway, 2006, 35, accessed 7/3/2014 from http://www.ssb.no/a/publikasjoner/pdf/rapp_200635/rapp_200635.pdf

Kitterød, R. H. (2012). Foreldrenes tidsbruk: Fedre deltar mer i husarbeid og omsorg [Time usage: Fathers participate more in household chores and caregiving]. Samfunnsspeilet, 26(4), 56-63.

Kwok, O-M., Underhill, A. T., Berry, J. W., Luo, W., Elliott, T. R., \& Yoon, M. (2008). Analysing longitudinal data with multilevel models: An example with individuals living with lower extremity intra-articular fractures. Rehabilitation Psychology, 53(3), $370-386$. 
Lamb, M. E. (2000). The history of research on father involvement: An overview. Marriage and Family Review, 29, 23-42. doi: 10.1300/J002v29n02_03

Lappegard, T. (2008). Changing the gender balance in caring: Fatherhood and the division of parental leave in Norway. Population Research and Policy Review, 27(2), 139-159.

Long, N. (2007). Learning from experience: Shifting from clinical parent training to broader parent education. Clinical Child Psychology and Psychiatry, 12, 385-392.

Lundahl, B. W., Tollefson, D., Risser, H., \& Lovejoy, M. C. (2008). A meta-analysis of father involvement in parent training. Research on Social Work Practice, 18(2), 97106. doi: $10.1177 / 1049731507309828$

MacKenzie, M. J. \& McDonough, S. C. (2009). Transactions between perception and reality: Maternal beliefs and infant regulatory behavior. In A. J. Sameroff (Ed.), The transactional model of development: How children and contexts shape each other (pp. 35-54). Washington: APA.

Marsiglio, W. (1991). Paternal engagement activities with minor children. Journal of Marriage and the Family, 53, 973-986. doi: 10.1111/j.0022-2445.2004<.00150.x Matheny, A. P., Wachs, T. D., Ludwig, J. L., \& Phillips, K. (1995). Bringing order out of chaos: Psychometric characteristics of the Confusion, Hubbub, and Order Scale. Journal of Applied Developmental Psychology, 16, 429-444. doi: 10.1016/01933973(95)90028-4.

Milkie, M., Mattingly, M., Nomaguchi, K., Bianchi, S., \& Robinson, J.P. (2004). The time squeeze: Parental statuses and feelings about time with children. Journal of Marriage and Family, 66(3), 739-761. doi: 10.1111/j.0022-2445.2004<.00150.x.

Nettle, D. (2008). Why do some dads get more involved than others? Evidence from a large British cohort. Evolution and Human Behavior, 29(6), 416-423. doi: 10.1016/j.evolhumbehav.2008.06.002. 
Normann, T. M. (2010). Sosial deltakelse. Svekket helse - mindre sosial kontakt [Social participation. Decreased health - less social contact]. Samfunnsspeilet, 5, 6 .

Parke, R. D., McDowell, D. J., Kim, M., Killian, C., Dennis, J., Flyr, M., \& Wild, M. N. (2002). Fathers' contributions to children's peer relationships. In C. S. Tamis-LeMonda \& N. Carbrera (Eds.), Handbook of father involvement: Interdisciplinary perspectives (pp. 141-167). Mahwah, NJ: Erlbaum.

Pleck, J. \& Masciadrelli, B. (2004). Paternal involvement in U.S. residential fathers: Levels, sources, and consequences. In Lamb, M. E. (Ed.). The role of the father in child development $\left(4^{\text {th }}\right.$ ed., pp. 222-271). New York: Wiley.

Program for foreldrerettleiing (2014). Accessed March 18, 2014, from Norwegian Directorate for Children, Youth and Family Affairs website,

http://www.bufetat.no/foreldrerettleiing/

Rohner, R. P., \& Veneziano, R. A. (2001). The importance of father love: History and contemporary evidence. Review of General Psychology, 5(4), 382-405.

Rosenberg, M. (1965). Society and the adolescent self-image. Princeton, NJ: Princeton University Press.

Russell, A., Aloa, V., Feder, T., Glover, A., Miller, H., \& Palmer, G. (1998). Sex-based differences in parenting styles in a sample with preschool children. Australian Journal of Psychology, 50(2), 89-99. doi: 10.1080/00049539808257539

Russell, D. (1996). The UCLA Loneliness Scale (Version 3): Reliability, validity, and factor structure. Journal of Personality Assessment, 66, 20-40. doi: 10.1207/s15327752jpa6601_2

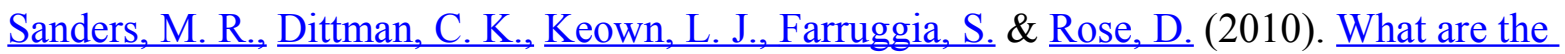
parenting experiences of fathers? The use of household survey data to inform decisions about the delivery of evidence-based parenting interventions to fathers. Child 
MOTHERS AND FATHERS ATTENDING ICDP 26

Psychiatry and Human Development, 41(5), 562-581. doi: 10.1007/s10578-010-0188-

$\mathrm{Z}$.

Schwarzer, R., \& Jerusalem, M. (Eds.) (1995). Generalized Self-Efficacy Scale. Windsor, UK: NFER-Nelson.

Shapiro, C. J., Prinz, R. J., \& Sanders, M. R. (2008). Population-wide parenting intervention training: Initial feasibility. Journal of Child and Family Studies, 17 (4), 457-466. doi: 10.1007/s10826-007-9170-1.

Sherr, L., Skar, A-M. S., Clucas, C., von Tetzchner, S., \& Hundeide, K. (2013). Evaluation of the International Child Development Programme (ICDP) as a community-wide parenting programme. European Journal of Developmental Psychology, 11(1), 1-17, doi: $10.1080 / 17405629.2013 .793597$

Skar, A-M. S., Sherr, L., Clucas, C., \& von Tetzchner, S. (2014). Evaluation of follow-up effects of the International Child Development Programme on caregivers in Mozambique. Infants \& Young Children, 27 (2), 120-135.

Spanier, G. (1976). Measuring dyadic adjustment: Nine scales for assessing marriage and similar dyads. Journal of Marriage and the Family, 38, 15-28.

Statistics Norway (2013). Indikatorer for kjønnslikestilling i kommunene 2011 [Indicators for gender equality in municipalities 2011], accessed 20/03/2013 from http://www.ssb.no/befolkning/ statistikker/likekom/aar/2013-03-05? fane $=$ tabell\&sort $=$ nummer $\&$ tabell $=100237$

Starrels, M. E. (1994). Gender differences in parent-child relations. Journal of Family Issues, 15-(1), 148-165. doi: 10.1177/019251394015001007.

Straus, M. A., Hamby, S. L., Finkelhor, D., Moore, D. W., \& Runyan, D. (1998). Identification of child maltreatment with the Parent-Child Conflict Tactics Scales: 
Development and psychometric data for a national sample of American parents. Child Abuse and Neglect, 22 (4), 249-270. doi: 10.1016/S0145-2134(97)00174-9.

Vittersø, J., Dyrdal, J., \& Røysamb, G. M. (2005). Utilities and capabilities: A psychological account of two concepts and their relation to the idea of a good life. Paper presented at the 2nd Workshop on Capabilities and Happiness, Milan, Italy.

Ware, J. E., Snow, K. K., Kosinski, M., \& Gandek, B. (1993). SF-36 health survey. Manual and interpretation guide. Boston: The Health Institute, New England Medical Center.

Zigmond, A.S. \& Snaith, R.P. (1983). The Hospital Anxiety and Depression Scale. Acta Psychiatrica Scandinavica, 67, 361-370. 
Table 1: Characteristics of fathers and mothers who completed questionnaires before and after the ICDP course: Frequencies

\begin{tabular}{|c|c|c|c|c|c|c|}
\hline & \multicolumn{2}{|c|}{ Fathers $(\mathrm{N}=36)$} & \multicolumn{2}{|c|}{ Mothers $(\mathrm{N}=105)$} & \multirow[t]{2}{*}{$X^{2}$} & \multirow[t]{2}{*}{$p$} \\
\hline & $N$ & $\%$ & $N$ & $\%$ & & \\
\hline \multicolumn{7}{|l|}{ Education } \\
\hline No higher education & 11 & 30.6 & 47 & 44.8 & 2.23 & .135 \\
\hline Higher education & 25 & 69.4 & 58 & 55.2 & & \\
\hline \multicolumn{7}{|l|}{ Civil status } \\
\hline Married/partner & 29 & 80.6 & 97 & 92.4 & 2.65 & .104 \\
\hline Separated/divorced/widow/single & 6 & 16.7 & 8 & 7.6 & & \\
\hline Missing & 1 & 2.8 & 0 & 0 & & \\
\hline \multicolumn{7}{|l|}{ Born in Norway } \\
\hline Yes & 33 & 91.7 & 95 & 90.5 & .05 & 1.00 \\
\hline No & 3 & 8.3 & 10 & 9.5 & & \\
\hline \multicolumn{7}{|l|}{ Employment } \\
\hline Full time & 31 & 86.1 & 47 & 44.8 & 19.71 & $<.001^{+*}$ \\
\hline Part time & 2 & 5.6 & 20 & 19.0 & & \\
\hline Other & 2 & 5.6 & 36 & 34.3 & & \\
\hline Missing & 1 & 2.8 & 2 & 1.9 & & \\
\hline \multicolumn{7}{|l|}{ Gender focus child } \\
\hline Male & 16 & 44.4 & 43 & 41.0 & .32 & .570 \\
\hline Female & 15 & 41.7 & 51 & 48.6 & & \\
\hline Missing & 5 & 13.9 & 11 & 10.5 & & \\
\hline
\end{tabular}

Note. ${ }^{+}$Fisher's Exact test was used, $*=<.05$. 
Table 2: Parenting, child and psychosocial measures with significant group differences before and/or after the course

\begin{tabular}{|c|c|c|c|c|c|c|c|c|c|c|c|c|c|}
\hline Variable & G & $\mathbf{N}$ & Bef & & $\mathbf{t}$ & $p$ & $d$ & $\mathbf{N}$ & & & $\mathbf{t}$ & $p$ & $d$ \\
\hline & & & $\mathrm{M}$ & SD & & & & & $\mathrm{M}$ & SD & & & \\
\hline Parenting & $\mathrm{F}$ & 30 & 20.97 & 3.22 & -4.26 & $<.001^{*}$ & .81 & 36 & 22.08 & 3.52 & -2.91 & $.006^{*}$ & .63 \\
\hline strategies & M & 90 & 23.20 & 2.19 & & & & 100 & 23.89 & 2.02 & & & \\
\hline Engage- & F & 28 & 2.87 & .95 & 3.00 & $.003^{*}$ & .64 & 32 & 2.54 & .62 & 3.02 & $.003^{*}$ & .64 \\
\hline ment & M & 87 & 2.30 & .84 & & & & 102 & 2.10 & .74 & & & \\
\hline $\begin{array}{l}\text { Manage- } \\
\text { ment }\end{array}$ & $\begin{array}{l}\mathrm{F} \\
\mathrm{M}\end{array}$ & $\begin{array}{l}20 \\
61\end{array}$ & $\begin{array}{l}2.11 \\
1.83\end{array}$ & $\begin{array}{l}.41 \\
.33\end{array}$ & 3.09 & $.003^{*}$ & .75 & $\begin{array}{l}26 \\
72\end{array}$ & $\begin{array}{l}1.88 \\
1.76\end{array}$ & $\begin{array}{l}.33 \\
.29\end{array}$ & 1.74 & .085 & .39 \\
\hline Activities & $\begin{array}{l}\mathrm{F} \\
\mathrm{M}\end{array}$ & $\begin{array}{l}18 \\
50\end{array}$ & $\begin{array}{c}94.11 \\
105.08\end{array}$ & $\begin{array}{c}11.73 \\
8.29\end{array}$ & -4.29 & $<.001^{*}$ & 1.08 & $\begin{array}{l}24 \\
58\end{array}$ & $\begin{array}{l}91.42 \\
102.9\end{array}$ & $\begin{array}{c}13.3 \\
12.02\end{array}$ & -3.81 & $<.001^{*}$ & .91 \\
\hline $\begin{array}{l}\text { Positive } \\
\text { discipline }\end{array}$ & $\begin{array}{l}F \\
M\end{array}$ & $\begin{array}{l}30 \\
79\end{array}$ & $\begin{array}{l}35.95 \\
45.09\end{array}$ & $\begin{array}{l}18.81 \\
20.61\end{array}$ & -2.20 & $.030^{*^{+}}$ & .46 & $\begin{array}{l}28 \\
88\end{array}$ & $\begin{array}{l}37.79 \\
53.35\end{array}$ & $\begin{array}{l}19.86 \\
22.54\end{array}$ & -3.27 & $.001^{*}$ & .73 \\
\hline Hrs father & $\begin{array}{l}\mathrm{F} \\
\mathrm{M}\end{array}$ & $\begin{array}{l}25 \\
62\end{array}$ & $\begin{array}{l}3.07 \\
2.00\end{array}$ & $\begin{array}{l}1.66 \\
1.61\end{array}$ & 2.77 & $.007^{*+}$ & .65 & $\begin{array}{l}21 \\
56\end{array}$ & $\begin{array}{l}4.35 \\
2.19\end{array}$ & $\begin{array}{l}4.96 \\
1.69\end{array}$ & 2.37 & .020 & .58 \\
\hline $\begin{array}{l}\text { weekdays } \\
\text { SDQ }\end{array}$ & $\mathrm{F}$ & 31 & 9.77 & 5.13 & .95 & .346 & .19 & 35 & 10.09 & 5.43 & 3.16 & $.003^{*}$ & .67 \\
\hline difficulties & M & 92 & 8.81 & 4.79 & & & & 94 & 6.89 & 4.07 & & & \\
\hline $\begin{array}{l}\text { Depress- } \\
\text { ion }\end{array}$ & $\begin{array}{l}\mathrm{F} \\
\mathrm{M}\end{array}$ & $\begin{array}{c}33 \\
100\end{array}$ & $\begin{array}{l}3.85 \\
2.96\end{array}$ & $\begin{array}{l}2.43 \\
2.27\end{array}$ & 1.92 & .057 & .38 & $\begin{array}{c}36 \\
102\end{array}$ & $\begin{array}{l}4.14 \\
2.83\end{array}$ & $\begin{array}{l}2.63 \\
2.54\end{array}$ & 2.63 & $.010^{*}$ & .51 \\
\hline $\begin{array}{l}\text { Self- } \\
\text { efficacy }\end{array}$ & $\begin{array}{l}\mathrm{F} \\
\mathrm{M}\end{array}$ & $\begin{array}{l}34 \\
99\end{array}$ & $\begin{array}{l}29.09 \\
28.46\end{array}$ & $\begin{array}{l}4.78 \\
5.49\end{array}$ & .59 & .556 & .12 & $\begin{array}{c}34 \\
101\end{array}$ & $\begin{array}{l}31.15 \\
28.72\end{array}$ & $\begin{array}{l}4.96 \\
5.64\end{array}$ & 2.23 & $.027^{*+}$ & .46 \\
\hline $\begin{array}{l}\text { Life satis- } \\
\text { faction }\end{array}$ & $\begin{array}{l}\mathrm{F} \\
\mathrm{M}\end{array}$ & $\begin{array}{c}34 \\
103\end{array}$ & $\begin{array}{l}23.68 \\
26.04\end{array}$ & $\begin{array}{l}5.99 \\
5.46\end{array}$ & -2.13 & $.035^{+}$ & .41 & $\begin{array}{c}34 \\
103\end{array}$ & $\begin{array}{l}24.32 \\
26.41\end{array}$ & $\begin{array}{l}5.51 \\
4.59\end{array}$ & -2.18 & $.031^{*^{+}}$ & .41 \\
\hline Loneliness & $\begin{array}{l}\mathrm{F} \\
\mathrm{M}\end{array}$ & $\begin{array}{c}35 \\
101\end{array}$ & $\begin{array}{l}13.69 \\
12.18\end{array}$ & $\begin{array}{l}4.34 \\
4.15\end{array}$ & 1.83 & .069 & .36 & $\begin{array}{c}35 \\
105\end{array}$ & $\begin{array}{l}13.40 \\
11.76\end{array}$ & $\begin{array}{l}4.21 \\
3.99\end{array}$ & 2.07 & $.040^{*}$ & .40 \\
\hline Life quality & $\begin{array}{l}\mathrm{F} \\
\mathrm{M}\end{array}$ & $\begin{array}{c}35 \\
104\end{array}$ & $\begin{array}{l}74.43 \\
80.00\end{array}$ & $\begin{array}{l}14.59 \\
13.31\end{array}$ & -2.09 & $.038^{+}$ & .40 & $\begin{array}{c}35 \\
104\end{array}$ & $\begin{array}{l}77.86 \\
81.25\end{array}$ & $\begin{array}{l}12.85 \\
14.03\end{array}$ & -1.26 & .209 & .25 \\
\hline
\end{tabular}

Note. $\mathrm{G}=$ group, $\mathrm{F}=$ fathers, $\mathrm{M}=$ Mothers, ${ }^{*}=<.05, d=$ Cohen's $\mathrm{d},{ }^{+}$gender effect became not significant after adjusting for confounders. 
Table 3: Fathers' and mothers' scores on parenting, child and psychosocial measures before and after the ICDP course

\begin{tabular}{|c|c|c|c|c|c|c|c|c|c|}
\hline \multirow[t]{2}{*}{ Measure } & Group & $\mathbf{N}$ & \multicolumn{2}{|c|}{ Before } & \multicolumn{2}{|c|}{ After } & $\mathbf{t}$ & $p$ & $d$ \\
\hline & \multicolumn{9}{|c|}{ Parenting measures } \\
\hline Parenting & Fathers & 30 & 20.97 & 3.22 & 22.53 & 2.57 & -4.00 & $<.001 *$ & .69 \\
\hline strategies & Mothers & 87 & 23.26 & 2.20 & 23.86 & 2.02 & -3.07 & $.003 *$ & .28 \\
\hline \multirow[t]{2}{*}{ Engagement } & Fathers & 25 & 2.95 & .95 & 2.53 & .61 & 3.03 & $.006^{*}$ & .53 \\
\hline & Mothers & 86 & 2.31 & .85 & 2.12 & .77 & 2.19 & $.032 *$ & .23 \\
\hline \multirow[t]{2}{*}{ Management } & Fathers & 18 & 2.13 & .44 & 1.92 & .34 & 2.80 & $.012 *$ & .53 \\
\hline & Mothers & 52 & 1.83 & .31 & 1.74 & .26 & 2.85 & $.006^{*}$ & .31 \\
\hline \multirow[t]{2}{*}{ Activities } & Fathers & 14 & 93.21 & 12.38 & 92.71 & 14.63 & .28 & .781 & .04 \\
\hline & Mothers & 37 & 105.13 & 8.69 & 105.40 & 8.23 & -.27 & .786 & .03 \\
\hline Positive & Fathers & 23 & 32.26 & 18.12 & 39.54 & 20.01 & -2.25 & $.035^{*}$ & .38 \\
\hline discipline & Mothers & 68 & 46.38 & 20.18 & 53.89 & 23.63 & -3.59 & $.001 *$ & .34 \\
\hline Hrs mother & Fathers & 10 & 3.59 & 2.28 & 2.83 & 1.96 & 2.18 & .057 & .36 \\
\hline with child & Mothers & 56 & 4.87 & 3.69 & 5.08 & 4.64 & -.42 & .679 & .08 \\
\hline Hrs father with & Fathers & 17 & 3.24 & 1.73 & 4.87 & 5.36 & -1.36 & .194 & .41 \\
\hline $\begin{array}{l}\text { child } \\
\text { Child measure }\end{array}$ & Mothers & 38 & 2.13 & 1.67 & 2.05 & 1.70 & .25 & .801 & .05 \\
\hline SDQ impact & Fathers & 31 & .74 & 1.24 & .35 & 1.08 & 1.62 & .117 & .34 \\
\hline SDQ & $\begin{array}{l}\text { Mothers } \\
\text { Fathers }\end{array}$ & $\begin{array}{l}86 \\
30\end{array}$ & $\begin{array}{l}.43 \\
9.70\end{array}$ & $\begin{array}{l}1.05 \\
5.20\end{array}$ & $\begin{array}{c}.20 \\
10.23\end{array}$ & $\begin{array}{c}.67 \\
5.34\end{array}$ & $\begin{array}{l}2.08 \\
-.70\end{array}$ & $\begin{array}{l}.041 * \\
.489\end{array}$ & $\begin{array}{l}.26 \\
.10\end{array}$ \\
\hline difficulties & Mothers & 89 & 8.84 & 4.68 & 6.97 & 4.10 & 4.92 & $<.001^{*}$ & .43 \\
\hline SDQ & $\begin{array}{l}\text { Fathers } \\
\text { Mothers }\end{array}$ & $\begin{array}{l}31 \\
91\end{array}$ & $\begin{array}{l}6.90 \\
7.46\end{array}$ & $\begin{array}{l}2.30 \\
2.06\end{array}$ & $\begin{array}{l}6.93 \\
7.68\end{array}$ & $\begin{array}{l}2.30 \\
2.13\end{array}$ & $\begin{array}{l}-.10 \\
-1.44\end{array}$ & $\begin{array}{l}.923 \\
.152\end{array}$ & $\begin{array}{l}.01 \\
.11\end{array}$ \\
\hline \multicolumn{10}{|c|}{$\begin{array}{l}\text { prosocial } \\
\text { Psychosocial measures }\end{array}$} \\
\hline \multirow[t]{2}{*}{ Commotion } & Fathers & 25 & 3.28 & 3.02 & 2.72 & 2.32 & 1.64 & .115 & .21 \\
\hline & Mothers & 74 & 2.61 & 2.56 & 2.19 & 2.49 & 2.28 & $.025 *$ & .17 \\
\hline Happiness & Fathers & 24 & 3.50 & .93 & 3.54 & .98 & -.30 & .770 & .04 \\
\hline with partner & Mothers & 74 & 3.54 & .80 & 3.61 & .82 & -.97 & .334 & .09 \\
\hline Anxiety & Fathers & 31 & 5.84 & 3.36 & 4.39 & 2.89 & 4.23 & $<.001 *$ & .46 \\
\hline & Mothers & 98 & 5.50 & 3.65 & 5.02 & 3.32 & 2.02 & $.046^{*}$ & .14 \\
\hline Depression & Fathers & 33 & 3.85 & 2.42 & 4.21 & 2.69 & -1.29 & .206 & .14 \\
\hline & Mothers & 97 & 2.95 & 2.30 & 3.87 & 2.59 & .47 & .637 & .38 \\
\hline Self- & Fathers & 33 & 29.03 & 4.84 & 31.03 & 4.99 & -3.73 & $.001 *$ & .41 \\
\hline efficacy & Mothers & 96 & 28.50 & 5.39 & 28.63 & 5.24 & -.10 & .922 & .02 \\
\hline Self-esteem & Fathers & 32 & 21.41 & 4.70 & 21.65 & 4.45 & -.65 & .522 & .05 \\
\hline & Mothers & 82 & 19.99 & 4.17 & 20.55 & 4.30 & -1.81 & .074 & .13 \\
\hline Life & Fathers & 32 & 23.50 & 6.14 & 24.19 & 5.59 & -1.32 & .196 & .12 \\
\hline & Mothers & 102 & 26.06 & 5.48 & 26.43 & 4.60 & -1.06 & .291 & .07 \\
\hline
\end{tabular}


MOTHERS AND FATHERS ATTENDING ICDP 31

\begin{tabular}{llcccccccc}
\hline Measure & \multicolumn{1}{c}{ Group } & \multicolumn{1}{c}{ N } & \multicolumn{2}{c}{ Before } & \multicolumn{2}{c}{ After } & t & $\boldsymbol{p}$ & $\boldsymbol{d}$ \\
\hline \multirow{2}{*}{ satisfaction } & & & Mean & SD & Mean & SD & & & \\
Loneliness & Fathers & 34 & 13.82 & 4.33 & 13.55 & 4.16 & .65 & .523 & .06 \\
& Mothers & 101 & 12.18 & 4.14 & 11.72 & 3.88 & 1.86 & .065 & .11 \\
Health & Fathers & 34 & 81.76 & 13.30 & 77.50 & 16.48 & 2.18 & $.037^{*}$ & .28 \\
& Mothers & 104 & 78.17 & 17.36 & 79.55 & 15.58 & -.91 & .365 & .08 \\
\multirow{4}{*}{ Life quality } & Fathers & 34 & 73.97 & 14.55 & 77.50 & 12.87 & -1.77 & .086 & .26 \\
& Mothers & 103 & 79.90 & 13.33 & 81.26 & 14.10 & -1.07 & .288 & .10 \\
Anger & Fathers & 35 & 3.20 & 1.01 & 2.92 & 1.05 & 2.05 & $.048 *$ & .27 \\
& Mothers & 102 & 3.30 & 1.28 & 3.12 & 1.01 & 1.61 & .111 & .16 \\
\hline
\end{tabular}

Note. $\boldsymbol{d}=$ Cohen's $d, * p<.05$

Note: Table 3 has slightly lower n's than Table 2 because only individuals with scores both before and after on the particular measure are included. 